DOI 10.37882/2223-2982.2021.06.12

\title{
ИНФОРМАЦИОННЫЙ ПОТЕНЦИАЛ КРАЕВЕДЧЕСКОЙ ЛИТЕРАТУРЫ ПРИ РАЗРАБОТКЕ ЦИФРОВОГО РЕСУРСА ПО ИСТОРИИ И СОВРЕМЕННОЙ ЖИЗНИ МОСКВЫ
}

\section{INFORMATION POTENTIAL OF LOCAL HISTORY LITERATURE IN THE DEVELOPMENT OF A DIGITAL RESOURCE ON THE HISTORY AND MODERN LIFE OF MOSCOW}

\section{T. Ershova}

Summary: The article is devoted to identifying the information potential of local history literature as a source for digital content on the history and modern life of Moscow. The article shows the possibilities of using reference literature on local history, the authors of which are professional historians. The article analyzes various materials of scientific and educational and local history journals and the possibilities of their application in the selection of content for a digital resource.

Keywords: history of Moscow, reference literature on local history, local history journals.

\author{
Ершова Тамара Витальевна \\ Д.и.н., профессор, Московский городской \\ педагогический университет \\ ershtamaris@yandex.ru
}

Аннотация: Статья посвящена выявлению информационного потенциала краеведческой литературы в качестве источника для цифрового контента по истории и современной жизни Москвы. В статье показаны возможности использования справочной литературы по краеведению, авторами которой являются профессиональные историки. Анализируются разнообразные материалы научно-просветительских и краеведческих журналов и возможности их применения при отборе контента для цифрового ресурса.

Ключевые слова: история Москвы, справочная литература по краеведению, краеведческие журналы.
$\mathrm{B}$ словиях возрастающего интереса к истории и современной жизни Москвы активно разрабатываются интернет-ресурсы, порой содержащие недостоверный, изобилующий ошибками и искажениями информации контент.

Гарантом размещения проверенного контента выступает реализация потенциала краеведческой литературы. В данной статье рассматривается возможность использования справочной литературы и периодических изданий научно-просветительского краеведческого характера как источника для наполнения цифрового контента.

Особое место занимает справочная литература по истории Москвы: энциклопедии, справочники, словари. Энциклопедия «Москва» вышла в 1980 году и содержала информацию о различных сторонах жизни Москвы: людях, улицах, зданиях, предприятиях, исторических событиях; а также сотни уникальных иллюстраций. Для всех, кто интересуется Москвой, это издание представляет собой ценный источник структурированной информации и интересных сведений. На настоящий день некоторая часть фактического материала устарела [33].

«Москва: Энциклопедия» уникальное справочное из- дание, вышедшее в 1997 году к 850-летию города. Главный редактор издания -С.О. Шмидт. Расположенные в алфавитном порядке статьи содержат информацию по разнообразным вопросам истории и современности Москвы. К работе над энциклопедией были привлечены специалисты различных направлений и специальностей, в том числе москвоведы [15].

В 2021 году в качестве дополнительного тома «Энциклопедия для детей. Российские столицы. Москва и Санкт-Петербург» вышло его 2-е издание, которое адресовано как школьникам, так и всем, кто интересуется историй, искусством, географией и краеведением. Энциклопедия включает разделы: история, архитектура, городской быт, политический центр, экономика, духовный центр, снабжена красочными иллюстрациями и фотографиями [32].

Важным направление в краеведении является исследование истории формирования названия московских улиц. Первые исследования в этом направлении появились еще в дореволюционный период: историко-археологические исследования И.М. Снегирева [24;25], историка А.А. Мартынова [13] и др.

В советский период П.Н. Миллер и П.В. Сытин в 1938 г. 
в работе «Происхождение названий улиц, переулков и площадей Москвы» рассмотрели вопрос переименования улиц и площадей [16]. В дальнейшем П.В. Сытин в своих сочинениях продолжал развивать эту тему вплоть до последней книги, вышедшей в 1959 г. «Откуда произошли названия улиц Москвы» [27].

В 1972 г. коллективом авторов был подготовлен справочник «Имена московских улиц», который переиздавался пять раз, последнее издание вышло в 1988 г. [7; 8].

Весь этот период внимание было сосредоточено на названиях улиц, переулков, площадей, а другие внутригородские географические объекты не были исследованы. Это положение изменилось с появлением первых москвоведческих топонимических работ. В книге Г.П. Смолицкой и М.В. Горбаневского «Топонимии Москвы» предпринята попытка выяснить происхождение названия города и Москвы-реки, а также топонимов и гидронимов, которые несут информацию об этих местах, Авторы рассматривают развитие топонимии на протяжении нескольких веков [23].

В «Лексическом атласе Московской области» А.Ф. Войтенко содержится материал по историческому краеведению и этнографии. Особое внимание уделяется особенностям говора населения. Исследование имеет неоценимое значение не только для исторической лексикологии русского языка, диалектологии, лингвогеографии, исторического краеведения, этнографии, но и общекультурную значимость [4].

В 1997 г. выходит книга исследователя московской старины, председателя общества «Старая Москва», члена комиссии правительства Москвы по переименованиям В.Б. Муравьев «Улочки-шкатулочки, московские дворы (Москва. Возвращенные имена)», в которой, рассказывается об истории переименованных улиц и переулков, которым возвращены исторические названия [18].

В издании, вышедшем в 2003 г., «Улицы Москвы. Старые и новые названия. Топонимический словарь-справочник», рассматривается происхождение названий улиц, площадей, вокзалов, станций метрополитена и железнодорожных станций, административных единиц, рек, озер, прудов Москвы с момента ее возникновения и до настоящего времени. Словарь-справочник был составлен по данным на 1 января 2002 г., содержит около 4 тысяч словарных статей. Авторы книги в течение ряда лет состояли в Городской межведомственной комиссии по наименованию территориальных единиц, улиц и станций метрополитена города Москвы. Это был первый опыт создания полного топонимического словаря такого большого города как Москва [29: с. 5].
Большая группа путеводителей содержит конкретные материалы по отдельным районам и улицам Москвы. Книга Ф.Л. Курлат и Ю.Е. Соколовского так и называется «С путеводителем по Москве» и призвана стать спутником читателей в прогулках по Москве. Путеводитель содержит информацию о достопримечательностях и памятных местах Москвы, о перспективном плане развития города, рассмотрено его центральное ядро, территории в пределах Садового кольца, в пределах автомобильного кольца, через весь город по Москве-реке и вокруг города по автомобильному кольцу. Фотографии, размещенные в путеводители, отражают жизнь москвичей 1970-х гг. [12].

Путеводитель «Москва в кольце Садовых» Ю.А. Федосюк состоит из очерков и посвящен истории улиц и площадей. Автор показывает старинный центр, архитектуру зданий, меняющиеся их функции, связанные с ними события, знакомит читателей с выдающимися москвичами. Путеводитель делится на четыре части: «Кремль. Вокруг Кремля»; «Радиальные улицы»; «Бульварное кольцо»; «Садовое кольцо». В работе широко использована мемуарная и художественная литература [30].

Ю. Александров в работе «Москва заповедная» рассматривает девять зон, ограниченных Садовым кольцом, от Китай-города до Заяузья, Кремль и Красную площадь. На схемах каждой зоны показано расположение наиболее значимых памятников архитектуры и дано их описание [1].

А.А. Васькин, М.Г. Гольштадт в фото-путеводителе по Старой Москве в границах Камер-Коллежского вала знакомят с историческими событиями, происходившими в районе Манежной Воздвиженки, Моховой, Калашного и Кисловского переулков, с историей памятников архитектуры. Дается подробное описание истории местности и строений. Особое внимание уделяют авторы персоналиям [3].

К.В. Стародуб, В.В. Емельянова, И.В. Краусова в путеводителе «Я люблю этот город вязевый...» знакомят с памятными литературными местами Москвы, через призму литературных произведений, показывают, что у каждого района свое сложившее «литературное лицо». В путеводитель включен указатель имен выдающихся литераторов, поэтов, драматургов и театральных деятелей. Предметно-тематический указатель охватывает широкий круг тем, которые отражены в путеводителе от адресов литераторов до литературных кофеен и салонов [26].

В книге Е. Кукиной и Р. Кожевникова «Рукотворная память Москвы», опубликованной в 1997 г., предпринята попытка систематизировать памятники. Поэтому, помимо исторического очерка по монументальной пластике, 
в книгу включена хронология сооружения памятников и мемориальных досок в Москве, алфавитный указатель памятников и мемориальных досок, указатель их авторов, а также топографический указатель. Автором привлечены справочники и путеводители по памятникам и памятным местам Москвы [11].

Книга историка, члена Правления Общества изучения русской усадьбы и ученого секретаря Фонда Возрождения русской усадьбы М.Ю. Коробко «Москва усадебная: Путеводитель», является путеводителем по подмосковным усадьбам, которые в настоящее время оказались включенными в черту Москвы. Эти усадьбы сохранились как архитектурные ансамбли. Путеводитель содержит обширный фактический и иллюстративный материал [10].

В связи со значительным расширением территории города и включением в нее значительных площадей Московской области, уместно отметить краткий путеводитель «Памятные места Московской области», подготовленный при участии Московского областного краеведческого музея. Материал систематизирован по двум основным разделам. Раздел І. включает исторические, архитектурно-художественные памятники и места, связанные с жизнью и деятельностью замечательных людей. В их число входят места, расположенные вблизи железных дорог, шоссейных дорог, водных транспортных путей. Раздел II. включает археологические памятники Московской области. В имеющемся указателе памятники подразделяются на места, связанные с именами общественных и политических деятелей, деятелей науки, литературы и искусства; исторические, историко-революционные и архитектурно-художественные памятники; археологические памятники; музеи, расположенные на территории Московской области. Путеводитель также имеет алфавитный перечень географических пунктов, упоминаемых в нем, схему Московской области и карты-схемы по железнодорожным, шоссейным и водным путям. Путеводитель снабжен иллюстрациями и фотографиями. Ряд памятных мест нужно рассматривать как пункты, вошедшие в Москву в 1960 году: Бабушкин, Кунцево, Люблино, Перово, Тушино и др. [20].

Значительный интерес представляют материалы, опубликованные в журналах. Обширный просветительский материал представляет популярный исторический журнал «Родина», который выходит с 1989 г. В нем содержится ценная информация по отдельным проблемам истории Москвы. Авторами являются известные историки, археологи, писатели, публицисты. Несомненный интерес представляют специальные номера, посвященные конкретному историческому периоду или теме. В № 9 за 2008 г. 4 статьи посвящены теме «100 лет российскому синематографу», а весь специальный выпуск 2019- «БКД.
История и истории Большого Кремлевского дворца».

В 1991 году вышел первый номер «Московского журнала», который продолжил традиции дореволюционного издания, основанного историком Н.М. Карамзиным. В журнале публикуются историко-краеведческие статьи, мемуары, воспоминания. В числе рубрик необходимо отметить рубрику «Достопримечательности Москвы», где размещены интересные материалы, например. по истории Павелецкого вокзала [28.]. В рубрике «Память места» - материал из фотоархива по истории площади Красные Ворота и Лермонтовская площади [17]. В рубрике «Записки москвоведа» размещены статьи по истории отдельных территорий и памятников истории и культуры исследователей Н.Ю. Бобковой, М.Ю. Коробко, И.Р. Монаховой, А.В. Шуховой, Д.Е. Юркова и др. [2; 9;14; $31 ; 34]$.

Особый интерес представляют материалы журналов, посвященных непосредственно истории и современности Москвы. В их числе журнал «Московское наследие», издаваемый с 2006 г. Учредителем журнала является Департамент культурного наследия города Москвы. На страницах журнала горожан информируют о деятельности Правительства Москвы в области сохранения и государственной охраны архитектурного достояния столицы, об интересных реставрационных проектах, размещены ценные историко-культурные сведения о памятниках. В журнале представлены уникальные архивные документы и редкие фотографии знакомых и малоизвестных памятников строй Москвы. Журнал поднимает дискуссионные темы для привлечения внимания общественности к актуальным проблемам сохранения и охраны культурного наследия. В подготовке материалов участвуют специалисты в области истории, архитектуры, краеведения и реставрации. [6: с. 4]. Необходимо также отметить, что точками бесплатного распространения журнала являются крупные книжные магазины, кафе, рестораны, клубы, музеи, АРТ-площадки, общественные организации, библиотеки, научно-исследовательские и учебные заведения, органы государственной власти, подведомственные учреждения. Электронная версия журнала «Московское наследие» размещена на официальном сайте мэра Москвы: Главы городской администрации [19].

В журнале публикуют стать, посвященные различным аспектам сохранения культурного наследия. Довольно часто появляются материалы по истории усадебных комплексов. В статье О.В. Докучаевой проведен анализ истории возникновения и развития архитектурно-паркового ансамбля «Царицыно», показан процесс реставрации и развития пейзажного парка [ 5].

Обстоятельная статья А. Потапенко по истории рож- 
дения и развития московского метрополитена освещает такие вопросы как его проектирование и строительство, функционирование в годы Великой Отечественной войны, решение задач дальнейшего развития в послевоенный период. Статья снабжена фотодокументами и основана на архивных материалах [21].

Обширный материал представлен в тематических выпусках журнала. Так, например, 75-летию Победы в Великой Отечественной войне посвящен № 1 (67) за 2020 г. Номера журналов за 2020 год освещали проблемы выявления и реставрации памятников по принципу административно-территориального деления города. Тематика номеров последовательно представлена: журнал №2(68) - «Север и ЮГ», № 3(69) - «Запада и Восток», № 4(70) - «Северо-Запад и Юго-Восток», № 5(71) - «ЮгоЗапад и Северо-Восток» и, наконец, №6(72) - «Новая Москва». Подводя итоги 2020 года главный редактор журнала Филипп Смирнов отмечал, что 2020 год оказался совершенно не похожим на многие предыдущие. И вопрос не только в том, что люди, зауженные санитарными и противоэпидемиологическими нормами, стали искать новые смыслы в уже привычных родных просторах. Нет, сами родные просторы и памятники истории и культуры как бы «дозрели» до новой выразительности. А ключом к пониманию города стал поиск созидательной и позитивной повестки - у нас тоже может быть интересно и хорошо. В статье отмечалось, что проведенные Департаментом культурного наследия города Москвы краеведческие диктанты под общим названием «Московский код» показали возросший интерес к краеведению и высокую востребованность знаний в области наследия, как материального, так и нематериального [22: с. 6-8]. Не случайно, Специальный выпуск 2020 года был посвящен реставрации-2020 в Москве. Журнал «Московское наследие» представляет уникальное издание, является ценным комплексным источником при разработке цифрового ресурса по истории и современной жизни Москвы.

Таким образом, краеведческая литература, опирающаяся на широкую достоверную источниковую базу, обладает значительным информационным потенциалом и может успешно служить источником при разработке цифрового ресурса по истории и жизни современной Москвы.

\section{ЛИТЕРАТУРА}

1. Александров Ю. Москва заповедная. М.: Изд-во «Московская правда», 1991.96 с.

2. Бобкова Н.Ю. «Еще не снесено» // Московский журнал. 2019. № 11 (347).

3. Васькин А.А., Гольштадт М.Г. Старая Москва в границах Камер-Коллежского вала. «По шелковой Воздвиженке, по замшевой Манежной»: Фотопутеводитель. - М.: Компания спутник+, 2002. 102 с.

4. Войтенко А.Ф. «Лексический атлас Московской области». М.: МОПИ им. Н.К. Крупской, 1991. 223 с.

5. Докучаева О.В. Архитектурно-парковый ансамбль «Царицыно» // Московской наследие. 2019. № 4 (64). С. $28-46$.

6. Емельянов А. Обращение к читателям // Московское наследие. 2016. № 1 (43). С.4-7.

7. Имена московских улиц/ под общ. ред. А.М. Пегова. М.: Моск. рабочий, 1972. 368 с.

8. Имена московских улиц. Путеводитель / под общ. ред. Г.К. Ефремова. 5-е изд. М., Моск. рабочий, 1988. 480 с.

9. Коробко М.Ю. Забытое Семеновское // Московский журнал. 2017. № 11(323).

10. Коробко М.Ю. Москва усадебная: Путеводитель. Серия «Новый московский путеводитель». М.: АНО ИЦ «Москвоведение», ОАО «Московские учебники», 2005. $335 \mathrm{C}$.

11. Кукина Е., Кожевников Р. Рукотворная память Москвы. М.: Моск. рабочий, 1997. 384 с.

12. Курлат Ф.Л. и Соколовский Ю.Е. С путеводителем по Москве. М.: Моск. рабочий, 1975. 456 с.

13. Мартынов А.А. Названия московских улиц и переулков с историческими объяснениями, составленными А. Мартыновым. Москва: тип. Е.Е. Потаповой, 1888. 244 c. [Электронный ресурc]. URL: https://elib.rgo.ru/safe-view/123456789/218444/1/bmF6dmFuaXIhX21vc2tvdnNraWhfdWxpY19pX3BlcmV1bGtvdl9zX 2lzdG9yaWNoZXNraS5wZGY= (дата обращения: 15.04 .20210

14. Монахова И.Р. Калитники //Московский журнал. 2020. № 12 (360).

15. Москва: Энциклопедия /Гл. ред. С.О. Шмидт. Сост. М.И. Андреев, В.М. Кареев. М.: Большая Российская энциклопедия, 1997. 976 с.

16. Миллер П.Н., Сытин П.В. Происхождение названий улиц, переулков и площадей Москвы. М.: Московский рабочий, 1938. 105 с.

17. Московский журнал. 2020. № 3 (351).

18. Муравьев В.Б. Улочки-шкатулочки, московские дворы (Москва. Возвращенные имена). М., «Тверская, 13», 1997. 269 с.

19. Официальный сайт мэра Москвы: Главы городской администрации URL: https://www.mos.ru/dkn/function/populiarizatciia/zhurnal-moskovskoe-nasledie/ (дата обращения: 08.04.2021).

20. Памятные места Московской области. Краткий путеводитель. 3-е изд., доп. и перераб. М.: Моск. рабочий, 1960. 736 с.

21. Потапенко А. Московский метро - лучший в мире. //М26-осковское наследие. 2018. № 2 (56). С. 26-42.

22. Смирнов Ф. Ищем единомышленников // Московское наследие. 2020. Спецвыпуск. Объекты реставрации. С. 6-8.

23. Смолицкая Г.П., Горбаневский М.В. «Топонимия Москвы». М.: Наука. 1982. 176 с. 
24. Снегирев И.М. Москва. Подробное историческое и археологическое описание города: в 2-х т. М.: Издание А. Мартынова, Почетного вольного общника Императорской Академии Художеств, 1865. Т.1. 210 с.

25. Снегирев И.М. Москва. Подробное историческое и археологическое описание города: в 2-х т. М.: Издание А. Мартынова, Почетного вольного общника Императорской Академии Художеств, 1874. Т.2. 221 с.

26. Стародуб К.В., Емельянова В.В., Краусова И.В. «Я люблю этот город вязевый...: Путеводитель по литературным местам Москвы. 2-е изд., доп. и перераб. М.: Моск. рабочий, 1990. 383 с.

27. Сытин П.В. Откуда произошли названия улиц Москвы. М.: Моск. рабочий, 1959. 367 с.

28. Толстов Ю.Г. Саратовский, он же Павелецкий // Московский журнал. 2018. № 4 (328).

29. Улицы Москвы. Старые и новые названия. Топонимический словарь -справочник. М.: Издательский центр «Наука, техника, образование», 2003.336 с.

30. Федосюк Ю.А. Москва в кольце Садовых. 2-е изд., перераб. и доп. М.: Моск. рабочий, 1991. 496 с.

31. Шухова А.В. Все начиналось с Горючки... // Московский журнал. 2021.2 (362).

32. Энциклопедия для детей. Дополнительный том. Российские столицы. Москва и Санкт-петербург.2-е изд.. испр. /Глав. Ред В.А. Володин.М.: Аванта+, 2001. $448 \mathrm{c}$.

33. Энциклопедия «Москва». М.: «Советская энциклопедия» (Москва), 1980. 688 с.

34. Юрков Д.Е. Затерянный уголок Новой Москвы // Московский журнал. 2018. № 7 (331).

(c) Ершова Тамара Витальевна (ershtamaris@yandex.ru).

Журнал «Современная наука: актуальные проблемы теории и практики»

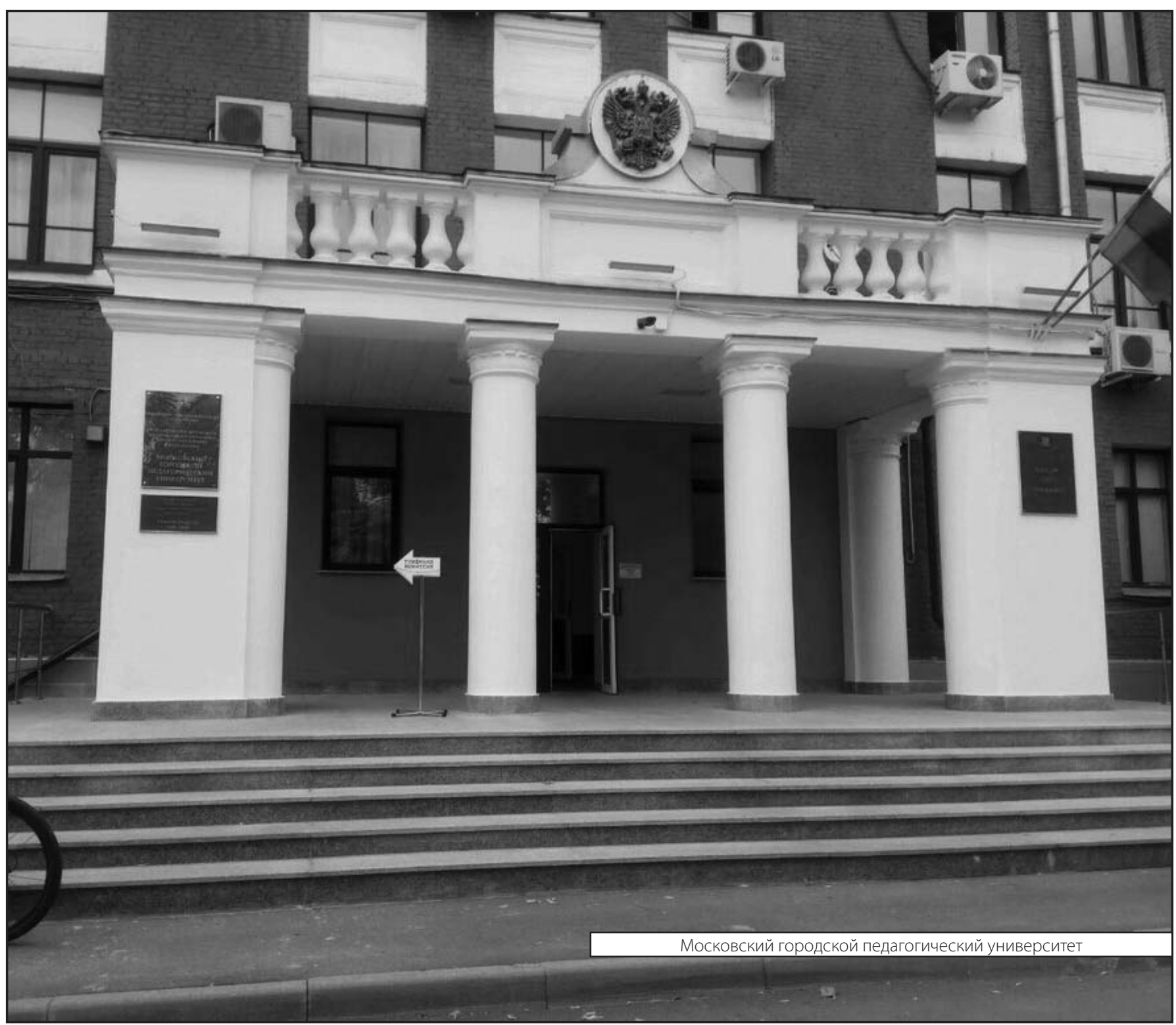

